\title{
IMPLEMENTASI REGULASI INTERNATIONAL CIVIL AVIATION ORGANIZATION (ICAO) PADA PENERBANGAN INDONESIA
}

\author{
Primadi Candra Susanto ${ }^{1}$; Yulianti Keke ${ }^{2}$ \\ ${ }^{1 \& 2}$ Institut Transportasi dan Logistik TRISAKTI, Jakarta, Indonesia \\ Email : primstrisakti@gmail.com, yuliakeke@gmail.com
}

ABSTRACT
Dalam dunia penerbangan pemenuhan (compliance) terhadap safety standard (standard
keselamatan) yang tinggi merupakan suatu keharusan yang mutlak. Penerapan keselamatan
penerbangan (aviation safety) perlu dilaksanakan pada semua sektor, baik pada bidang transportasi /
operasi angkutan udara, kebandaraudaraan, navigasi, perawatan dan perbaikan serta pelatihan yang
mengacu pada aturan International Civil Aviation Organization (ICAO) Pada dasarnya dengan
mematuhi prosedur keselamatan yang berlaku maka dapat meningkatkan keselamatan dalam
penerbangan sehingga dapat tercipta penerbangan yang aman, nyaman dan selamat. Kegiatan
penerbangan dan angkutan udara mempunyai sifat internasional yang menonjol, baik dari aspek
ekonomis komersial maupun aspek pengaturannya. Angkutan udara dewasa ini sudah merupakan
suatu industri global yang melibatkan hampir semua Negara didunia dan hukum udara yang
mengatur industri tersebut membuktikan bahwa keseragaman pengaturan dapat dicapai secara
internasional. Penelitian ini merupakan hasil penelitian mengenai Organisasi Internasional tentan
Peran Internasional Civil Aviation Organization (ICAO) dalam mengimplementasikan standar
keselamatan penerbangan internasional.




\section{PENDAHULUAN}

Penerbangan merupakan bagian dari sistem transportasi yang mempunyai karakteristik mampu bergerak dalam waktu cepat, menggunakan teknologi tinggi, padat modal, manajemen yang handal, serta memerlukan jaminan keselamatan dan keamanan yang optimal, di era sekarang ini dengan persaingan bisnis yang semakin ketat, tentu harus didukung oleh sarana transportasi yang aman dan mendukung termasuk transportasi udara. Kebutuhan akan pelayanan transportasi bersifat sangat kualitatif dan mempunyai ciri yang berbeda-beda sebagai fungsi dari waktu, tujuan perjalanan, frekuensi, jenis kargo yang diangkut, dan lain-lain. Kebutuhan akan pelayanan transportasi bersifat sangat kualitatif dan mempunyai ciri yang berbeda-beda sebagai fungsi dari waktu, tujuan perjalanan, frekuensi, jenis kargo yang diangkut, dan lain-lain. Pelayanan transportasi yang tidak sesuai dengan kebutuhan akan pergerakan menyebabkan sistem transportasi tersebut tidak berguna. Kebutuhan akan pergerakan bersifat sebagai kebutuhan turunan. Pergerakan terjadi karena adanya proses pemenuhan kebutuhan. Untuk mendukung pertumbuhan ekonomi, maka diperlukanlah sarana transportasi udara yang memiliki standard pelayanan dan keselamatan yang optimal.

Pelayanan transportasi yang tidak sesuai dengan kebutuhan akan pergerakan menyebabkan sistem transportasi tersebut tidak berguna. Kebutuhan akan pergerakan bersifat sebagai kebutuhan turunan. Pergerakan terjadi karena adanya proses pemenuhan kebutuhan. Untuk mendukung pertumbuhan ekonomi, maka diperlukanlah sarana transportasi udara yang memiliki standard pelayanan dan keselamatan yang optimal. Untuk menunjang hal tersebut Indonesia pada tanggal 1 Mei 2004 telah resmi menjadi anggota ICAO (International Civil Aviation Organitation). Dengan masuknya Indonesia menjadi anggota ICAO Indonesia aktif dalam Pelaksanaan misi ICAO di berbagai penerbangan sipil dunia sehingga dengan begitu indonesia akan memiliki dampak positif di berbagai pelaksanaan peraturan baik dalam bentuk pembinaan, pengawasan, pencerahan, pendidikan maupun kerjasama pelatihan bagi komunitas penerbangan domestik.

Dengan meningkatnya keselamatan penerbangan di dalam negeri maka akan mendorong peningkatan demand transportasi udara sehingga nanti akan mendukung terciptanya suatu pertumbuhan perekonomian bangsa sehingga tingkat keselamatan terjamin. kita harus yakin bahwa suatu saat nanti 
Indonesia juga dapat menjadi pelaku yang diandalkan di pasar penerbangan internasional. Singapore Airlines merupakan salah satu negara yang menjadi operator penerbangan negara yang menerbangi 62 kota di 35 negara dan di 6 benua.

ICAO lahir didahului dengan terbentuknya "panitia persiapan pembentukan ICAO” yang terkenal dengan PICAO (Provisional Civil Aviation Organization). Terdiri dari 6 langkah yang diringkas :

1. PICAO terbentuk resmi tanggal 6 Juni 1945 di Montreal Canada.

2. Berfungsi sampai dengan tanggal 4 April 1947.

3. ICAO resmi terbentuk tanggal 4 April 1947, di Montreal Canada.

4. Menjadi badan dibawah PBB tanggal 13 Mei 1947.

5. Setiap negara anggota PBB (negara yang merdeka dan berdaulat) dapat menjadi anggota ICAO.

International Civil Aviation

Organization (ICAO) adalah badan dibawah Perserikatan Bangsa-Bangsa

$(\mathrm{PBB})$

yang kegiatannya menyiapkan peraturan penerbangan sipil internasional, melakukan distribusi dan melakukan pemantauan serta evaluasi terhadap penerapannya. ICAO lahir dari negara-negara sekutu Amerika, tepatnya pada tanggal 01 November 1944 sampai dengan
07 Desember 1944 (selama lima minggu), 52 (lima puluh dua) negara-negara sekutu Amerika berkumpul di Chicago mereka mengadakan komperensi yang dikenal sebagai Chicago Conference 1944 dan membahas masalahmasalah penerbangan sipil yang harus diselesaikan pada akhir masa perang dunia.

Organization (ICAO) yang merupakan sebuah badan khusus PBB yang ditugaskan untuk mengkoordinasi dan mengatur perjalanan udara internasional. Konvensi ini menetapkan aturan wilayah udara, pendaftaran pesawat udara dan keselamatan, dan merinci hak-hak penandatangan terkait dengan perjalanan penerbangan sipil internasional. Setiap negara memiliki suatu sistem penerbangan dimana sistem penerbangan ini guna untuk mempermudah perjalanan jarak jauh hingga terasa dekat. Namun dalam operasinya setiap bandara membutuhkan manajemen keselamatan yang baik demi menjaga kenyamanan penumpang. Oleh karena itu, di buatlah organisasi penerbangan yang beguna untuk membahas segala yang berhubungan dengan penerbangan baik itu tingkat keselamatan, pengoperasiannya serta hukum dalam penerbangan. Sehingga di buatlah organisasi internasional yang nantinya sangat berperan dalam mengendalikan serta mengawasi maupun membahas tentang sistem penerbangan dunia. 
Organisasi penerbangan dunia salah satunya adalah ICAO (International Civil Aviation Organization) Sebuah lembaga perserikatan bangsa-bangsa dimana lembaga ini mengembangkan teknik dan prinsip navigasi udara internasional serta dapat menbantu perkembangan perencanaan dan pengembangan angkutan udara internasional untuk memastikan pertumbuhannya lancar dan aman jika di gunakan. Lembaga ini secara resmi mulai berdiri pada tanggal 4 april 1947.

Kebijakan ICAO ada di dalam 18 Annex dan berbagai dokumen lainnya yang berasal dari turunan suatu keputusan yang di ambil dalam sidang umum dan sidang council, sidang ini adalah sidang tentang kebijakan - kebijakan yang berlandaskan tentang kebenaran kebenaran ilmiah yang dapat dipertanggung jawabkan. 18 Annex konvensi chicago 1944 berdasrkan standar kelayakan yang di tunjukkan kepada seluruh anggota ICAO untuk menjamin keselamatan penerbangan internasional, Annex ini juga menjadi landasan-landasan ICAO untuk membentuk International Standart and Recommended Proctices (ISRPs/SARPs) delapan belas Annex tersebut adalah:

1. Annex 1 - Personal Licensing merupakan peraturan tentang izin bagi awak pesawat dalam mengatur lalu lintas udara dan personil pesawat udara.
2. Annex 2 - Rules of The Air merupakan suatu aturan-aturan yang berkaitan dengan penerbangan secara visual dan penerbangan dengan menggunakan instrument.

3. Annex 3 - Meterological Service for International Air Navigation merupakan sebuah ketentuan mengenai layanan meteorologikal bagi navigasi internasional dan pemberitahuan hasil observasi meteorology dari pesawat udara.

4. Annex 4 - Aeronautical Charts merupakan peraturan tentang spesifikasi peta aeronautical yang digunakan dalam penerbangan internasional.

5. Annex 5 - Units of Measurement to be Used in Air and Ground Operation merupakan ketentuan mengenai satuansatuan ukuran yang digunakan dalam penerbangan.

6. Annex 6 - Operation Aircraft merupakan suatu aturan yang mengatur tentang spesifikasi yang akan menjamin keselamatan dalam penerbangan diseluruh dunia yang berada pada tingkat keamanan diatas tingkat minimum yang telah ditetapkan.

7. Annex 7 - Aircraft Nationality and Registration Marks merupakan persyaratan-persyaratan umum untuk 
membuat pendaftaran dan identifikasi pesawat udara.

8. Annex 8 - Airworthiness of Aircraft merupakan pengaturan tentang standar kelayakan udara dan pemeriksaan pesawat udara berdasarkan prosedur yang seragam.

9. Annex 9 - Facilitation merupakan suatu ketentuan mengenai standar fasilitasfasilitas Bandar udara yang akan menunjang kelancaran dan masuknya pesawat udara, penumpang dan cargo di Bandar Udara.

10. Annex $10 \quad-\quad$ Aeranutical Communications merupakan suatu aturan yang mengatur tentang prosedur standar, sistem, dan peralatan komunikasi.

11. Annex 11 - Air Traffic Service merupakan suatu yang memuat tentang pengadaan dan pengawasan terhadap lalu lintas udara, informasi penerbangan dan layanan pemberitahuan serta peringatan mengenai keadaan bahaya.

12. Annex 12 - Search and Rescuce merupakan suatu yang memuat ketentuan tentang pengorganisiran dan pemberdayaan fasilitas dalam mendukung pencarian pesawat yang hilang.
13. Annex 13 - Aircraft Accident Investigation ialah merupakan sebuah ketentuan tentang keseragaman dan pemberitahuan investigasi, dan laporan mengenai kecelakaan pesawat.

14. Annex 14 - Aerodrome merupakan ketentuan tentang spesifikasi dan desain dan kegiatan dibandar udara.

15. Annex 15 - Aeronautical Information merupakan metode untuk mengumpulkan cara penyebaran informasi yang dibutuhkan dalam operasional dalam penerbangan.

16. Annex 16 - Enviromental Protectum merupakan suatu yang memuat ketentuan mengenai sertifikat ramah lingkungan, pengawasan terhadap kebisingan yang ditimbulkan oleh emisi dari mesin udara.

17. Annex 17 - Enviromental Protectum merupakan ketentuan mengenai perlindungan keamanan penerbangan sipil internasional dari tindakan melawan hukum.

18. Annex 18 - The Safe Transport of Dangerous Godds by Air merupakan suatu aturan yang mengatur tentang tanda, cara mengepak, dan pengangkutan cargo yang berbahaya.

Keselamatan Penerbangan adalah suatu keadaan yang terpenuhinya 
persyaratan keselamatan dan pemanfaatan wilayah udara, pesawat udara, Bandar udara, angkutan udara, navigasi penerbangan, serta fasilitas penunjang dan fasilitas fasilitas umum lainnya. Keamanan dan keselamatan dalam sebuah penerbangan sipil sangatlah penting dan tergantung pula pada keamanan dari bandar udara yang memberangkatkan pesawat tersebut. Mengingat banyaknya ancaman dari tindakan gangguan melawan hukum baik saat pesawat di darat maupun di udara.

\section{LANDASAN TEORI}

Dalam UU Penerbangan, penerbangan sebagai salah satu moda transportasi tidak dapat dipisahkan dari moda-moda transportasi lain yang ditata dalam sistem transportasi nasional, yang dinamis dan mampu mengadaptasi kemajuan dimasa depan, mempunyai karakteristik mampu mencapai tujuan dalam waktu cepat, berteknologi tinggi dan memerlukan tingkat keselamatan tinggi, perlu lebih dikembangkan potensinya dan ditingkatkan peranannya sebagai penghubung wilayah baik nasional maupun internasional, sebagai penunjang, pendorong, dan penggerak pembangunan nasional demi peningkatan kesejahteraan rakyat.

Dalam UU Penerbangan, Angkutan Udara adalah setiap kegiatan dengan menggunakan pesawat udara untuk mengangkut penumpang, kargo, dan/atau pos untuk satu perjalanan atau lebih dari satu bandar udara ke bandar udara yang lain atau beberapa bandar udara. Definisi ICAO Adalah Sebuah Badan Khusus Perserikatan Bangsa-Bangsa Beranggotakan Negara-Negara Anggkota PBB Yang Diwakili Oleh Otoritas Penerbangan Sipil Nasionalnya (Civil Aviation Authority). Misalnya Untuk Indonesia Yaitu Direktorat Jenderal Perhubungan Udara Atau Disingkat DJPU Yang Dulu di Kenal Dengan Sebutan Direktorat Sertifikasi Kelayakan Udara atau Disingkat DSKU.

$$
\text { Tugas ICAO (International Civil }
$$
Aviation Organization) Bertugas Mengatur Urusan Teknis Operasional Penerbangan Seperti :

1. Lalu-Lintas Udara (Air Traffic).

2. Frekuensi Radio.

3. Markings Pada Landasan Pacu.

4. Alat bantu Navigasi.

5. Syarat-Syarat Kelaikan Pesawat Udara (Airworthiness).

6. Keselamatan Penerbangan (Flight Safety).

7. Standar Keterampilan Pilot (Aircrew).

8. Teknisi Pesawat Udara (Mechanic).

9. Landasan Pacu (Runway).

10. Lapangan Terbang (Airport). 11. ATC (Air Traffic Control). 
12. Memfasilitasi Lintas Batas Prosedur Penerbangan Sipil International dan Juga Mengadakan Inspeksi Penerbangan Untuk Mencegah Pelanggaran Hukum Penerbangan Internatioanl Yang Telah di Tetapkan Bersama Oleh Para Anggotanya Dalam Konvensi Chicago di Tahun 1994.

Penerbangan adalah segala sesuatu yang berkaitan dengan penggunaan wilayah udara, pesawat udara, bandar udara, angkutan udara, keamanan dan keselamatan penerbanagan serta kegiatan dan fasilitas penunjang lain yang terkait. Menurut K Martono, Kemajuan ilmu pengetahuan dan teknologi yang pesat dibidang penerbangan telah mampu meningkatkan mutu pelayanan penerbangan dan juga mampu menciptakan alat-alat penerbangan canggih dan beraneka ragam. Perkembangan teknologi penerbangan mempunyai dampak yang positif terhadap keselamatan penerbangan dalam dan luar negeri.

Transportasi udara adalah sistem penerbangan yang melibatkan banyak pihak. Dalam dunia penerbangan pemenuhan (compliance) terhadap safety standard (standar keselamatan) yang tinggi merupakan suatu keharusan yang mutlak. Penerapan keselamatan penerbangan (aviation safety) perlu dilaksanakan pada semua sektor, baik pada bidang transportasi/operasi angkutan udara, kebandaraudaraan, navigasi, perawatan dan perbaikan serta pelatihan yang mengacu pada aturan International Civil Aviation Organization (ICAO). Menurut Yaddy Supriyadi, ICAO merupakan suatu badan khusus Perserikatan Bangsa-Bangsa dan berkedudukan di Montreal. Maksud dan tujuan dari ICAO adalah untuk mengembangkan prinsip-prinsip dan tehnik-tehnik navigasi udara internasional dan membina perencanaan dan perkembangan angkutan udara internasional. Kebijakan-kebijakan ICAO yang dituangkan dalam 18 Annex dan berbagai dokumen turunannya melalui keputusan yang diambil dalam sidang Umum dan Sidang Majelis, adalah kebijakan-kebijakan berlandaskan kebenaran-kebenaran ilmiah yang dapat dipertanggung jawabkan.

Pesawat Udara Sipil adalah adalah pesawat terbang atau pesawat udara yang digunakan untuk mengangkut penumpang sipil beserta bagasi dan kargo (dengan kapasitas tertentu). Syarat-syarat mengenai pengangkutan sipil diatur dalam undang-undang, baik pemerintah maupun internasional melalui lembaga PBB bernama ICAO (International Civil Aviation organization). Dalam Moegandi, Dalam bahasa inggrisnya penerbangan adalah Aviation yang berarti the operation of aircraft (penerbangan adalah pengoperasian pesawat terbang) dan the production of aircraft 
(penerbangan adalah produksi pesawat terbang). Dalam artian lain penerbangan merupakan satu kesatuan sistem yang terdiri atas pemanfaatan wilayah udara, pesawat udara, bandar udara, angkutan udara, navigasi penerbangan, keselamatan, dan keamanan, lingkungan hidup, serta fasilitas penunjang, dan fasilitas umum lainnya. Dari definisi tersebut diatas secara eksplisit mendefinisikan bahwa penerbangan sipil merupakan pemanfaatan wilayah udara dengan menggunakan pesawat udara sipil. Pesawat udara diklasifikasikan menjadi beberapa jenis. Menurut Konvensi Paris 1919, klasifikasi pesawat udara diatur dalam Bab VII tercantum dalam pasal $30,31,32$, dan 33, masing-masing mengatur jenis pesawat udara, pesawat udara militer. Menurut pasal 30 Konvensi Paris 1919, pesawat udara terdiri dari 3 jenis, masing-masing pesawat udara militer, pesawat udara yang sepenuhnya digunakan untuk dinas pemerintahan seperti bea cukai, polisi, dan pesawat udara lainnya.

\section{METODE PENELITIAN}

Eksistensi rangkaian suatu metode penelitian guna untuk mendukung pembahasan dan analisa terhadap pokok-pokok permasalahan di atas maka diperlukan adanya pengumpulan data yang kemudian untuk dikonstruksikan. Dalam penyusunan penulisan ini dilakukan pengumpulan data melalui penelitian kepustakaan (library research). Dengan Library Research akan dihasilkan karya ilmiah yang mempunyai materi, kualitas, bobot kebenaran ilmiah yang dapat dipertanggung jawabkan, di mana bahan-bahan/data-data tersebut didapat dari : Buku-buku ilmiah yang tersebut dalam literature, naskah-naskah peraturan perundang-undangan, majalah, surat kabar, internet, dan tulisan karya ilmiah, Dengan menggunakan metode ini diharapkan artikel ini ini dapat menjadi suatu karya ilmiah yang baik dan berguna untuk pengembangan ilmu pengetahuan khusus nya dibidang kedirgantaraan.

\section{PEMBAHASAN}

Tujuan penerbangan adalah untuk mewujudkan penyelenggaraan penerbangan yang selamat, aman, cepat, lancar, tertib dan teratur, nyaman dan berdayaguna, dengan biaya yang terjangkau oleh daya beli masyarakat, dengan mengutamakan dan melindungi penerbangan nasional, menunjang pemerataan, pertumbuhan dan stabilitas, sebagai pendorong, penggerak, dan penunjang pembangunan nasional serta mempererat hubungan antar bangsa. ICAO dibentuk dalam rangka untuk mengembangkan prinsip-prinsip serta teknikteknik navigasi udara secara internasional. Selain itu tujuan lain adalah untuk membina perencanaan dan perkembangan angkutan udara 
dalam ruang lingkup internasional. Kepentingan serta tujuan utama ICAO adalah Keamanan \& Keselamatan, Efisiensi dan Keteraturan (Security \& Safety, Efficiency, Regularity). Dengan tujuan tersebut, ada beberapa kegiatan yang bisa dilakukan ICAO selaku organisasi penerbangan internasional. Seperti menyiapkan peraturan penerbangan sipil internasional, melakukan distribusi juga melakukan pemantauan plus melakukan evaluasi penerapannya. Sifat peraturan dari hasil Konferensi Chicago adalah SARPs atau Standard And Recommended Practice. Artinya terdapat peraturan yang merupakan keharusan atau sifatnya "mandatory" serta ada peraturan yang hanya bersifat "recommended"/direkomendasikan. Dari hasil Chicago Conference tersebut menghasilkan beberapa 'produk', salah satunya adalah dihasilkannya 6 (enam) dokumen. Enam dokumen tersebut adalah The Convention on International Civil Aviation (Chicago Convention 1944), International Air Services Transit Agreement (IASTA), Draft of 12 Tehnical Annexes (Annex 1 - 12), Standard form of Bilateral Agreement (Chicago Form Agreement), International Air Transport Agreement (IATA), dan The Provisional International Civil Aviation Organization (PICAO).
Organisasi Penerbangan Sipil Internasional (ICAO) melakukan Universal Safety Oversight Audit Programme (USOAP)/ Audit Keselamatan Penerbangan di Indonesia. Audit secara langsung (on site) atau proses ICVM (ICAO Coordinated Validation Mission) ini dilakukan setelah melakukan audit dokumen (off site).

Ada 8 area yang menjadi fokus ICVM dari ICAO, yaitu Legislation (LEG), Organization (ORG), Personnel Licensing (PEL), Airworthiness (AIR) , Operations (OPS), Air Navigation (ANS), Aircraft Investigation (AIG) dan Aerodromes (AGA). Indonesia merupakan anggota ICAO (International Civil Aviation Organization) sejak 27 April 1950 dan menjadi anggota Dewan ICAO (Council of ICAO) untuk Kategori III sejak 1962. Selama periode keanggotaan Dewan tersebut, Indonesia memiliki kantor perwakilan di ICAO Headquarter, Montreal. Kantor tersebut dipimpin oleh Wakil Indonesia (Indonesian Representative) untuk ICAO yang berasal dari Kementerian Perhubungan RI. Kantor ini memiliki peran penting yang menjembatani kepentingan Indonesia dalam bidang penerbangan sipil (c.q. Ditjen Perhubungan Udara Kementerian Perhubungan RI) dengan ICAO, terutama mengenai perkembangan terkini dalam hal keselamatan dan keamanan 
penerbangan di dunia internasional. Selain itu, keberadaan kantor juga berperan dalam menyediakan data dan informasi kepada ICAO dan anggota ICAO lainnya mengenai kebijakan Pemerintah RI dalam bidang penerbangan sipil Indonesia.

\section{Mengingat pentingnya peran Kantor} Perwakilan Indonesia di ICAO dalam mengikuti dan berpartisipasi dalam pembahasan standar maupun rekomendasi terkait penerbangan sipil internasional serta dalam upaya memperjuangkan kepentingan Indonesia di ICAO, Pemerintah Indonesia masih membuka Kantor Perwakilan tersebut meskipun Indonesia tidak terpilih lagi menjadi anggota Council of ICAO pada tahun 2001 sampai dengan diputuskan untuk ditutup. Seiring dengan pertumbuhan dunia penerbangan sipil yang makin pesat ditandai banyaknya maskapai penerbangan di Indonesia, pembangunan Bandar Udara di berbagai kawasan Indonesia, dan meningkatnya perhatian dunia internasional terhadap aspek keselamatan dan keamanan penerbangan di Indonesia yang tercemin dalam laporan audit USOAP (Universal Safety Oversight Audit Program) ICAO meliputi seluruh aspek keselamatan penerbangan, legislasi, regulasi, organisasi, prosedur dan personalia, mendorong Pemerintah Indonesia dan ICAO untuk memperkuat hubungan dan kerjasama yang erat antara kedua belah pihak.
Kerja sama Indonesia-ICAO ini dilandasi dengan adanya Deklarasi antara Pemerintah RI dan ICAO untuk memperkuat keselamatan penerbangan Indonesia ("The Declaration between the Government of the Republic of Indonesia and the International Civil Aviation Organization on Enhancing Aviation Safety in Indonesia"), ditandatangani di Bali, oleh Presiden ICAO, Mr. Roberto Kobeh Gonzalez dan Menteri Perhubungan RI, Jusman Syafii Jamal di Bali, 2 Juli 2007.

Deklarasi ini menekankan pada :

a. Pentingnya kedua pihak bekerja sama dan memperkuat kapasitas pengawasan keselamatan penerbangan (safety oversight capacity).

b. Menyediakan dukungan finansial dan sumber daya yang dibutuhkan.

c. Menerapkan program keselamatan penerbangan nasional (national safety program), termasuk sistem manajemen keselamatan (safety management systems), penerapan transparansi, pengembangan budaya keselamatan.

d. Penyebaran data terkait mengenai keselamatan penerbangan. Sebagai tindak-lanjut penandatanganan Deklarasi Bali tersebut, ICAO dan Pemerintah Indonesia telah menjalin kesepakatan berbentuk Management Service Agreement (MSA) yang terdiri dari 
4 Annexes yang ditandatangani oleh Sekjen ICAO dan Dirjen Perhubungan Udara Kementrian Perhubungan Republik Indonesia, yakni :

a) MSA Annex 1 mengenai Enhancement of Safety Oversight Capability of the Indonesian Directorate General for Civil Aviation (DGCA).

b) MSA Annex 2 mengenai Civil Aviation Transformation Team (CATT) for Impementation of Civil Aviation Strategic Action Plans (CASAP).

c) MSA Annex 3 mengenai Upgrading of Civil Aviation Training.

d) MSA Annex 4 mengenai Assistance to the Representation of Indonesia to the International Civil Aviation Organization.

Penguatan struktur dan kapasitas institusi Pemerintah Republik Indonesia yang menangani penerbangan sipil, dalam hal ini Direktorat Jenderal Penerbangan Sipil Kementrian Perhubungan Republik Indonesia merupakan elemen penting sesuai dengan kebijakan ICAO yang terangkum dalam program USOAP ICAO untuk memperkuat keselamatan penerbangan, sekaligus mempromosikan peningkatan struktur dan kapasitas institusi yang menanganinya.
Realisasi penguatan struktur dan kapasitas institusi tersebut adalah melalui program MSA Annex 4 mengenai dukungan dan bantuan ICAO untuk membuka kembali Kantor Kepentingan Indonesia di ICAO. MSA Annex 4 ini telah ditandatangani Dirjen Perhubungan Udara Kementerian Perhubungan Republik Indonesia dan Sekjen ICAO pada 27 Januari 2010 dan 12 Februari 2010.

Indonesia juga telah menyiapkan implementasi Carbon Offsetting and Reduction Scheme for Internasional Aviation (ICAO CORSIA) bersama dengan beberapa negara dalam komitmen pengurangan emisi $\mathrm{CO} 2$ dan saat ini sedang dalam proses akreditasi pengukur independen untuk CORSIA. Juga telah meluncurkan sistem Airport Collaborative Decision Making (A-CDM) serta sistem penanggulangan bencana penerbangan akibat debu vulkanik yakni Integrated Web based Aeronautical Information System Handling (IWISH) yang dapat digunakan sebagai alat alternative oleh ICAO dan negara - negara anggota lainnya.

ICAO dalam sangkut pautnya terhadap dunia penerbangan memiliki 6 program sebagai berikut :

a. Safety, meningkatkan keselamatan penerbangan sipil secara global.

b. Security, meningkatkan keamanan penerbangan sipil secara global. 
c. Efficiency, meningkatkan efesiensi dan operasi penerbangan.

d. Environment Protection, meminimalisir efek buruk dari dunia penerbangan terhadap lingkungan.

e. Continuity, menjaga keberlangsungan operasi penerbangan.

f. Rule of law, meningkatkan standard peraturan penerbangan sipil.

Berkaitan dengan ICAO, sebagai salah satu anggota ICAO, kondisi penerbangan di indonesia juga harus selalu diperhatikan. Termasuk salah satu yang menjadi sorotan adalah terkait dengan skor keamanan ICAO yang didapatkan maskapai penerbangan Indonesia. Skor ICAO ini walaupun hanya berupa angka namun mampu menjadi indikator apakah faktor keamanan dan keselamatan penerbangan di Indonesia benar-benar terjamin.

\section{KESIMPULAN}

Penerbangan sipil meliputi transportasi udara (pengangkutan komersial melalui udara), penerbangan non-komersial (penerbangan pribadi), non-transportasi komersial (debu dan tanaman), infrastruktur (bandara dan fasilitas navigasi udara), dan manufaktur (pesawat terbang, mesin dan avionik). Secara tradisional transportasi udara, sebagai unsur utama penerbangan sipil, mengalami pertumbuhan yang lebih tinggi daripada industri lainnya.
Permintaan transportasi udara terkait erat dengan perkembangan ekonomi. Dapat dikatakan bahwa transportasi udara adalah salah satu indikator ekonomi sebuah Negara. Kontribusi transportasi udara dan industri penerbangan sipil berpengaruh terhadap ekonomi kawasan baik lokal, nasional maupun regional. Output dan pekerjaan yang terkait dengan penerbangan sipil memberikan efek ganda atau efek gelombang terhadap industri lain dalam konstelasi ekonomi. Potensi ekonomi dapat dilihat dari data yang mengungkapkan bahwa penerbangan sipil mengambil porsi empat puluh persen nilai ekspor manufaktur dunia dan melayani 45 persen pariwisata internasional. Selain itu, layanan penumpang dan bisnis, pengiriman surat/ barang dan maskapai penerbangan membeli berbagai macam produk dan layanan dari bandara dan pengelola navigasi penerbangan udara, aircraft manufacturing dan industri jasa, yang pada gilirannya melibatkan ketergantungan kepada banyak pemasok. Ringkasnya, lebih dari empat setengah persen output ekonomi dunia dapat dikaitkan dengan komponen transportasi udara penerbangan sipil.

Selain itu sebagai anggota ICAO, sangat tepat jika Indonesia melalui Ditjen Perhubungan Udara telah membina kemitraan dengan otoritas negara anggota lain dan berbagai organisasi Internasional antara lain World Tourism 
Organization (UNWTO), Pasific Travel Association Asia (PATA), Forum Ekonomi Dunia (WEF), dan World Travel and Tourism Council (WTTC). Sementara membangun konektivitas dan menjaga kredibilitas di mata dunia, kiranya penting untuk dilakukan pembenahan terus-menerus delapan parameter keberhasilan dunia penerbangan Indonesia yaitu legislation, organization, operation, airworthiness, accident investigation, air navigation services, dan aerodromes. Perbaikan tersebut diperlukan Indonesia agar menjadi anggota Dewan ICAO Kategori III yaitu negara yang mewakili secara geografis. Kini peran ICAO telah berubah, ICAO saat ini melakukan tiga peran. ICAO bukan hanya berperan sebagai pembuat standar saja, tetapi juga (peran kedua) memonitor kepatuhan (compliance) yaitu memonitor pelaksanaan standar- standar yang telah ditetapkan untuk kemudian (peran ketiga) meminta segera negara mematuhi dan melaksanakan standar-standar yang belum atau tidak dipatuhi. ICAO kini berperan sebagai Proactive International Regulatory Body.

\section{DAFTAR PUSTAKA}

A Moegandi. 1996. Mengenal Dunia Penerbangan Sipil, Pustaka Sinar Harapan, Jakarta.
K. Martono. 1999. Tim Analisis Awak Pesawat Udara Sipil, Jakarta.

Undang-Undang Republik Indonesia No.

15 Tahun 1992 Tentang Penerbangan.

Undang-Undang Republik Indonesia No.1 Tahun 2009 Tentang Penerbangan.

Yaddy Supriadi. 2012. Keselamatan Penerbangan Teori \& Problematika, Telaga Ilmu Indonesia, Tangerang.

https://sekolahpenerbangan.org/pengerti an-icao/ diakses pada tanggal 11 Juli 2020.

http://lontar.ui.ac.id. Diunduh Pada Tanggal 11 Juli 2020. 